Volume 9, No.1, January - February 2020

International Journal of Advanced Trends in Computer Science and Engineering

Available Online at http://www.warse.org/IJATCSE/static/pdf/file/ijatcse08912020.pdf

https://doi.org/10.30534/ijatcse/2020/08912020

\title{
Factors Influencing the Adoption of Internet Banking System Using UTAUT Combined TTF at Private Bank Indonesia
}

\author{
Nilo Legowo ${ }^{1}$, Kinzie Vitalli ${ }^{2}$ \\ ${ }^{1}$ Information Systems Management Department, Binus Graduate Program-Master of Information Systems \\ Management, Bina Nusantara University,Jakarta Indonesia 11480, nlegowo@ binus.edu \\ ${ }^{2}$ Information Systems Management Department, Binus Graduate Program-Master of Information Systems \\ Management, Bina Nusantara University,Jakarta Indonesia 11480, kinzie.vitalli@gmail.com
}

\begin{abstract}
Internet banking helps users to be able to access their bank accounts without having to interact physically with the bank. Almost all leading banks already have an internet banking system. For banks, the internet banking system helps banks to be able to compete in the banking industry while providing excellent service to their customers. This study aims to evaluate the use of the internet banking system that was just launched by one of the banks in Indonesia using UTAUT combined with Task Technology-Fit and Trust. The subjects of this study were 230 users of internet banking registered in one of the branches. In this study, we assess the effect of performance expectancy, effort expectancy, social influence, task-technology-fit and trust on the behavior intention. And other purpose is to assess the effect of facilitating conditions and behavior intention on use behavior. By using the structural equation model (SEM) and SmartPLS software, the results of this study show that performance expectancy, social influence, and trust have a positive effect on behavior intention. While facilitating conditions and behavior intention have a positive effect on use behavior in the use of the internet banking system.
\end{abstract}

Key words : System evaluation, Internet banking, UTAUT, Task Technology-Fit,.

\section{INTRODUCTION}

Internet Banking or here in after referred to as IB is the use of the internet as a channel for banking services [1]. Included are various traditional banking services such as access to account information, fund transfer and also bill payment. Electronic transactions through IB are a form of bank service development that utilizes information technology and has changed the banking business strategy which initially focused on developing or expanding branches to focus on developing technology-based service and innovations.

IB has emerged as one of the most profitable e-commerce applications in the last decade [2]. IB has also changed the way banks and their customers interact, before the IB is available, customers must visit a branch or come to the nearest ATM to make a transaction, but now with IB adoption, customers can make transactions from anywhere and anytime through a computer, smartphone or other wireless media while connected to the internet.

In the early 2000s, several banks in Indonesia began implementing Internet Banking and offered it to their customers as part of banking services. This phenomenon continues to grow until now many banks have participated in implementing Internet Banking. So that it can be said that currently internet banking is no longer a luxury item but is already a service that must exist in each bank [3]. Internet Banking has become one of the determining factors for people in choosing banking services. Without having internet banking services, one bank will have difficulty in acquiring new customers and will also have difficulty in maintaining the existing customers' loyalty. Internet banking provides flexibility and convenience for its users in accessing banking services.

One of the leading national private banks in Indonesia has just launched an IB in September 2016. The IB system is expected to help banks in increasing the number of new customers and also help in efforts to increase customer loyalty to the banks. In a study conducted by senior management, it was revealed that the IB adoption rate was still very low compared to the initial target.

This research is aimed to study the internet banking adoption in Bank XYZ using the Unified Theory of Acceptance and Usage of Technology (UTAUT), with two additional factors were integrated: Task Technology-Fit (TTF) and Trust. The analysis based on the received responses from the questions we gave to users indicate the factors that influence internet banking usage.

\section{THEORETICAL BACKGROUND}

Information technology has spread widely into people's lives, we can see so many equipments around us that are equipped with information technology such as smart phones, smart TV, smart watch and so on. Increased technological innovation and its application produce amazing benefits and have brought changes to human life. 
According to Vishal Goyal, at al. that existing regulations in India all banking transactions must be carried out only in Indian currency, rupees which can be an obstacle to interoperability between Indian and existing mobile payments can be done worldwide. In addition, there are demographic challenges that exist in India is that in Indian countries the languages spoken are different in parts of the region. Most of India's population still lives in rural areas and not everyone understands the same language. So it's very important to make software that is easy for users to use and is available in a variety of languages[4].

In general, research on information systems is intended to evaluate the level of acceptance of a system by users in an organization. The design development and acceptance of information technology has received substantial attention in the past few decades. Many theoretical models have been proposed to provide an explanation for end-users of acceptable behavior. One that is widely used in research on evaluating acceptance of a system is the Unified Theory of Acceptance and Usage of Technology (UTAUT) model by Venkatesh et al, which has been applied and empirically tested in various domains [5 ].

In an organization such as a private company and government institutions, a lot of system development is aimed at such as to improve company performance or improve public services. Not infrequently the investment needed to develop the system is very costly and takes a long time to process. Evaluation of the results of the development of information systems must be carried out to determine the level of acceptance by the user and also to find out whether the targets set out, in the beginning, have been fulfilled, [6 ].

\subsection{UTAUT}

UTAUT which stands for Unified Theory of Acceptance and Use of Technology is a very popular theory and has been widely used in various researches to conduct user acceptance research on information technology. UTAUT developed by Venkatesh et al integrating the features that are considered the most successful of the eight leading theories of technology acceptance that have existed before and then combined them into one theory.

Based on studies on the previous eight systems acceptance models, Venkatesh et al state that seven constructs determine the intention to use the system. Four out of seven constructs are believed to be the direct determinant of behavioral intention and use behavior, namely: performance expectancy, effort expectancy, social influence and facilitating conditions.

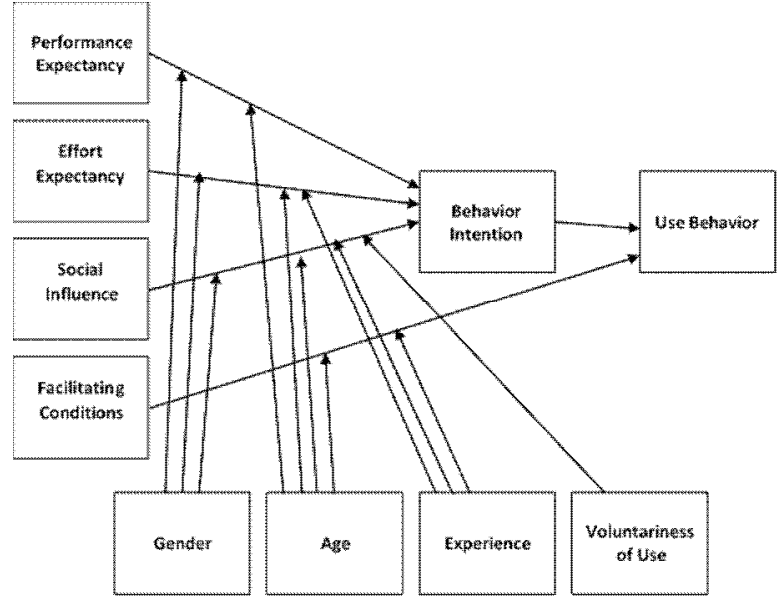

Figure 1: Unified Theory of Acceptance and Use of Technology (UTAUT) [4]

The UTAUT model is also influenced by several moderator variables, namely Gender, Age, Experience and Voluntariness of use. The moderator variables can moderate the influence of independent variables on behavior intention and use behavior in the use of new technology.

Performance expectancy is defined as the degree to which a person believes that the use of a system will help him improve work performance. There are five constructs of the previous research models that are related to performance expectancy, namely: perceived usefulness (TAM / TAM2 and C-TAM-TPB), extrinsic motivation (MM), job fit (MPCU), relative advantage (IDT) and outcome expectation (SCT).

Effort expectancy is defined as the level of ease in using the system. Social influence is defined as a factor of people and the surrounding social environment that can affect the use of the system. Facilitating conditions are defined as factors in whether or not there are compatibility related obstacles that can affect system usage.

Behavior intention is the level at which someone has planned to do or will not do something in the future. Behavior intention (BI) is defined as the degree to which a person has formulated a conscious plan to do or not do some determined future behavior [7]. According to Venkatesh, behavior intention has been widely used as a predictor of system use.

\subsection{Trust}

Trust is the willingness of a party to be vulnerable to the actions of other parties based on the expectation that the party who is trusted will take an action that is important for those who trust, regardless of the ability to monitor or control the other party. This definition of trust applies to a relationship with another party that can be identified and is considered able to act and react to the willingness of the party who believes. This definition of trust applies both to relationships between individuals and between individuals and organizations [8 ].

Trust is determined by the tendency of the party who believes in trust, ability, benevolence and integrity from the trusted party. The following is an explanation of the Trust construction. 


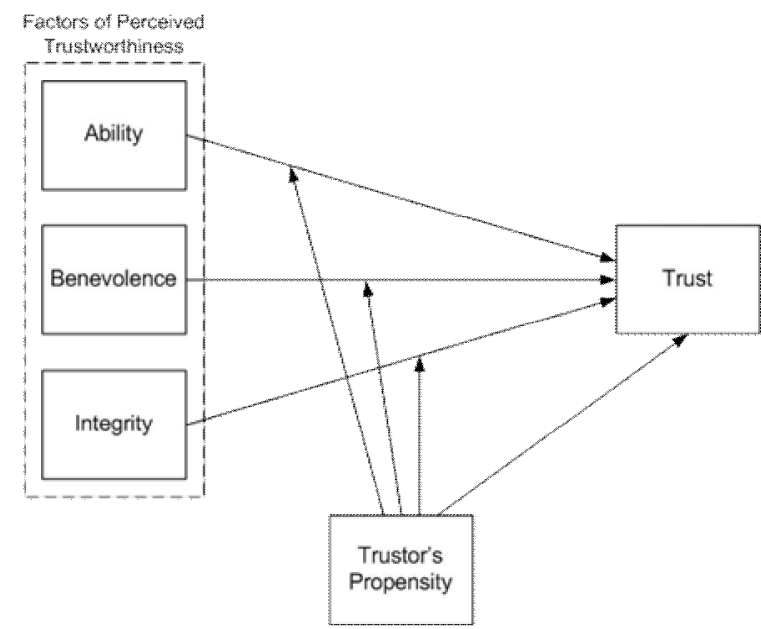

Figure 2: The TRUST Model [7]

The propensity to trust is a behavior that leads to a measurable level of hope about one's beliefs. Trends may be considered as a desire to trust others. The tendency will affect how much trust a trustee has before real information on a trusted party is available. People with different growth experiences, different personality types, and different cultural backgrounds will vary in their tendency to trust [9]. An extreme example of this case is what is commonly called blind faith.

Ability is a combination of skills, competencies, and characteristics that allow one party to influence in certain fields. Because the field of ability is specific, the trusted party can be very competent in certain fields. However, this party may have deficiencies in other fields. For example, even though someone can be trusted to carry out analytic tasks related to the technical area, but maybe the individual is not trusted to start in contact with important customers. Thus, trust is a very specific field [10 ].

Besides the motive for getting profit, benevolence or virtue is the extent to which a person who is trusted wants to do good to the giver of trust. Benevolence shows that those who are trusted have some special attachments to those who believe. An example of benevolence is the relationship between a mentor (trustee) and a student (trustor). Mentors want to help students, even though mentors are not needed to help, and there are no extrinsic awards for mentors. Benevolence is the perception of a positive orientation from the one who believes in the believer.

The relationship between integrity and trust is related to the perception of the person who believes that the person who is trusted can obey the principles that can be accepted by the trustee. McFall illustrates why compliance and acceptance of principles are important. He mentions that someone who adheres to the principle shows his integrity. However, if the principle is not considered acceptable by the trusted party, then that person will not be considered to have integrity [11].

\subsection{Task Technology-FIT}

Task Technology-Fit (TTF) developed by Goodhue and Thompson in 1995 is one of the behavioral theories that is used to assess the process of user adoption of system usage. The TTF model emphasizes the importance of conformity between the availability of technology and the needs of tasks in the daily work of users. The TTF model explains the acceptance of system usage by using four constructs as follows:

1. Task Characteristic. Defined as a task or work carried out by an individual to convert inputs into outputs.

2. Technology Characteristic. Viewed as a tool used by someone to carry out their work. Concerning research on information systems, technology refers to computer systems including hardware and software.

3. Individual characteristic. It is an individual who uses a system to help with daily work. Individual characteristics such as training, experience using computers and motivation determine how well he can use the system.

4. Task Technology-Fit. Defined as the degree to which technology helps a person in doing his work. More specifically, the TTF is a link between requirements, individual abilities and functions and features of the technology.

Goodhue defines task technology-fit as the basis for the user to evaluate and measure the success of an information system. This success of the information system will be demonstrated by the increase of performances, especially the performance of individuals in the organization. In the TTF perspective, technology is seen as something that is directly related to the completion of individual tasks. Task technology-fit, in this case, defines the extent to which the function of technology fits the task requirements and individual abilities [12].

More specifically, TTF is an adjustment between the need for tasks, individual abilities, and technological functions. The priority of TTF is the interaction between tasks, technology, and individuals. Goodhue also stated that individual performance achievement related to a series of individual tasks achievements with the support of information technology. Individual performance measurement sees the impact of information system technology on the effectiveness of task completion, improve user's performance, productivity and creativity. 


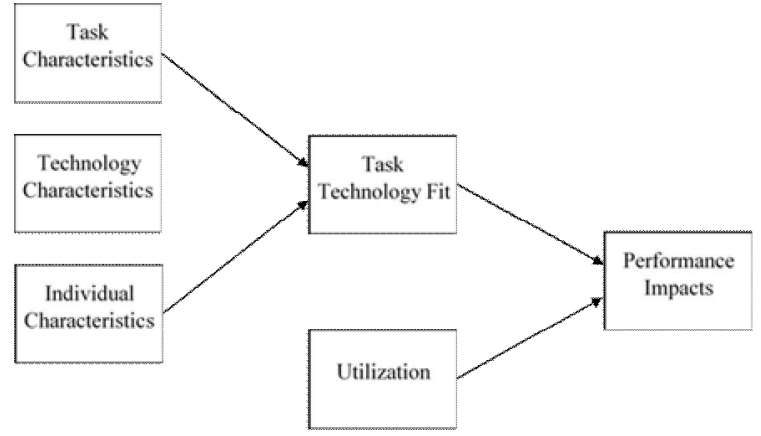

Figure 3: The Task Technology-Fit Model [12]

\subsection{UTAUT Extension}

The research conducted by Oliviera et al in 2014 of the adoption of mobile banking using a combination of the UTAUT, TTF and Trust models. The research conducted by Oliviera et al in 2014 of the adoption of mobile banking using a combination of the UTAUT, TTF and Trust models. This research conducted in countries wich has highest mobile banking adobtion rate in one of European Union in Portugal. The study combines the strengths of the three system acceptance models [13]. The results of the study were facilitating conditions and intention behavior directly affecting the adoption of mobile banking. While performance expectancy, Initial Trust, characteristic tasks and technology-fit tasks together influence the behavior intention.

The research conducted by Oliveira et al formulated and empirically tested the integration model to explain the decision to adopt mBanking at the individual level. The results of the study indicate that the proposed model has explanatory power that is substantial and strong in several circumstances. Not only the integration of TTF and Trust with UTAUT is theoretically interesting, but also empirically significant, because it explains why many variations for the intention to adopt and adapt itself are much higher than those indicated by previous adoption studies on adoption intentions. The following diagram shows the research model used by Oliveira et al.

The constructs that explain this study the adoption of mBanking that the most important namely behavior intention, facilitating conditions, task technology-fit (TTF), technology characteristic, performance expectation and initial trust (ITrust). The significant overall effect of technology-fit, technology characteristic, performance expectancy, and initial trust tasks on mBanking adoption proves the importance of the research model developed [13].

This study presents a holistic approach to future on the adoption of new IS technology with highlighting the usefulness of integrating three existing theories, namely, UTAUT, TTF, and Trust (ITM).

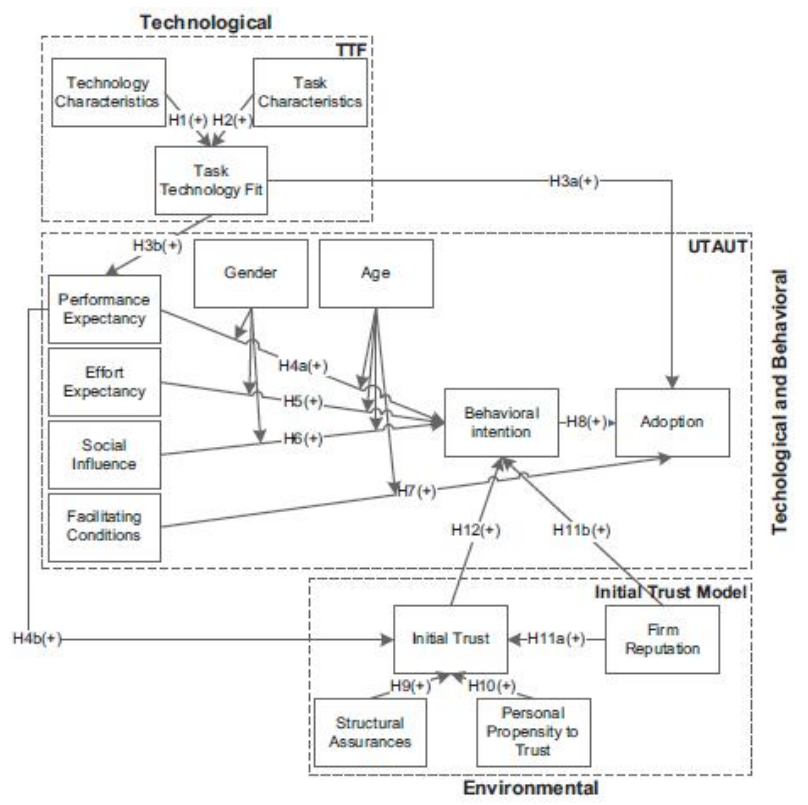

Figure 4: Integration of UTAUT, TTF and Trust [12]

\subsection{Literature Review}

Some researchers have integrated UTAUT with variable other models to study problems related to the acceptance and use of technology. Yoo et al in his research entitled "The roles of intrinsic motivators and extrinsic motivators in promoting e-learning in the workplace: A case from South Korea", studied the impact of extrinsic motivation and on employee intentions to use e-learning at work. The conceptualize effort expectancy, performance expectancy, social influence, and facilitating conditions as components of extrinsic motivation [14].

According Guo and Barnes, in their research entitled "Explaining Purchasing Behavior within World of Warcraft" also adopted the same theoretical foundation to test consumer purchase intentions in cyberspace, but they viewed effort expectancy and performance expectancy as components of influencing motivation extrinsic [15].

According Venkatesh et al in said that there had been some progress regarding studies regarding UTAUT integration with other theoretical models that had made some progress. But there are still some things that need to be improved, especially concerning the lack of integration of the UTAUT moderation variable [16].

Table 1: Research combined UTAUT with other models.

\begin{tabular}{lll}
\hline Researchers & Model Theory & UTAUT Functions \\
\hline Zhou et al & Task-technology & Effort expectancy, \\
{$[17]$} & fit theory and & Performance \\
& UTAUT & expectancy, \\
& & facilitating conditions \\
& & and social influences, \\
& & affect user adoption \\
&
\end{tabular}




\begin{tabular}{|c|c|c|}
\hline $\begin{array}{l}\text { Venkatesh et } \\
\text { al [18] }\end{array}$ & $\begin{array}{l}\text { IS continuance } \\
\text { model } \\
\text { (Bhattacherjee \& } \\
\text { Premkumar, 2004) } \\
\text { and trust (e.g., } \\
\text { McKnight, } \\
\text { Choudhury, \& } \\
\text { Kacmar, 2002) }\end{array}$ & $\begin{array}{l}\text { Performance } \\
\text { expectancy, effort } \\
\text { expectancy, social } \\
\text { influences, and } \\
\text { facilitating conditions } \\
\text { as pre-usage beliefs, } \\
\text { disconfirmation, }\end{array}$ \\
\hline $\begin{array}{l}\text { Miltgen, } \\
\text { Popovic, \& } \\
\text { Oliveira [19] }\end{array}$ & $\begin{array}{l}\text { Technology } \\
\text { acceptance model } \\
\text { (TAM), diffusion } \\
\text { of innovations } \\
\text { (DOI), and } \\
\text { UTAUT }\end{array}$ & $\begin{array}{l}\text { facilitating conditions } \\
\text { and Social influences } \\
\text { affect user acceptance }\end{array}$ \\
\hline $\begin{array}{l}\text { Lian \& Yen } \\
{[20]}\end{array}$ & $\begin{array}{l}\text { Innovation } \\
\text { resistance theory } \\
\text { and UTAUT }\end{array}$ & $\begin{array}{l}\text { Main effects of } \\
\text { UTAUT factor as the } \\
\text { drivers acceptance of } \\
\text { online shopping }\end{array}$ \\
\hline
\end{tabular}

\section{METHODOLOGY}

\subsection{Research Model}

The following figure shows the research model which will be used as foundation for creating the hypothesis. All variables which mentioned in the previous section are represented by boxes and arrows.

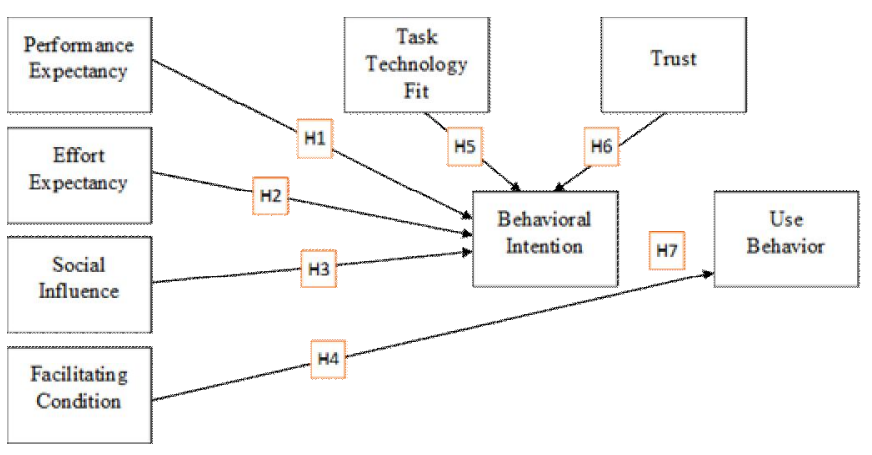

Figure 5: Research Model

\subsection{Hypothesis}

Based on the modified UTAUT model which also taking into account the Task Technology-Fit model, and the Trust model, the hypothesis are as follows:

H1: Performance Expectancy positively influences Behavior Intention

H2: Effort Expectancy positively influences Behavior Intention

H3: Social Influence positively influences Behavior Intention

H4: Facilitating Conditions influences positively Use Behavior

H5: Task Technology-Fit positively influences Behavior Intention

H6: Trust positively influences Behavior Intention

H7: Behavior Intention positively influences Use Behavior

\subsection{Data Collection}

In the period of the survey conducted between October and December 2018, the questionnaire was distributed in two stages. The first stage is to distribute questionnaires for testing the validity and reliability. And the second stage is to distribute questionnaires to get respondents according to the number of samples needed in this study. The first questionnaire has 35 questions and received around 38 respondents. After testing the validity and reliability test of 38 respondents there were about 11 questions that were excluded from the questionnaire because they did not pass the validity and reliability test.

Then in distributing the questionnaire stage 2 which contains only 24 questions that have passed the validity test and the reliability test, we received 240 respondents who provided the answer. 10 out of the 240 respondents were not valid because they provided incomplete answers. Therefore, this study only used 230 respondents. This amount is sufficient to meet the sample needed in this study which were calculated using the Slovin formula.

\subsection{Variables}

In this research, the UTAUT, TTF and Trust variables that will be used are only the main variables. As follows: effort expectancy, performance expectancy, facilitating conditions , social influence, behavior intention and use behavior, task technology-fit and trust. The above variables are grouped into two categories. The following table shows the six exogenous variables which are variables whose values are not influenced by other variables or also called independent variables.

Table 2: Dependent Variable.

\begin{tabular}{cll}
\hline Code & \multicolumn{1}{c}{ Variables } & \multicolumn{1}{c}{ Definition } \\
\hline $\mathrm{Y}$ & Behavior Intention & $\begin{array}{l}\text { Behavioral intention is the } \\
\text { level at which someone has } \\
\text { planned to do or will not do } \\
\text { something in the future. }\end{array}$ \\
\hline $\mathrm{Z}$ & Usage Behavior & $\begin{array}{l}\text { The level of behavior of use or } \\
\text { level of system adoption by } \\
\text { users. }\end{array}$ \\
\hline
\end{tabular}

From Table 2. it can be seen that there then the second variable group is the endogenous variable which is a variable whose value is influenced by other variables or also called the dependent variable, namely:

Table 3: Independent Variable.

\begin{tabular}{cll}
\hline Code & \multicolumn{1}{c}{ Variables } & \multicolumn{1}{c}{ Definition } \\
\hline X1 & Performance & Levels that indicate the \\
& Expectation & $\begin{array}{l}\text { extent to which users believe } \\
\text { that performance will } \\
\text { increase using the system. }\end{array}$ \\
\hline X2 & Effort Expectation & $\begin{array}{l}\text { defined as the level of ease in } \\
\text { using the system. }\end{array}$ \\
\hline
\end{tabular}




\begin{tabular}{cll}
\hline X3 & Social Influence & $\begin{array}{l}\text { defined as a factor of people } \\
\text { and the surrounding social } \\
\text { environment that can affect } \\
\text { the use of the system. }\end{array}$ \\
\hline X4 & $\begin{array}{l}\text { Facilitating } \\
\text { Conditions }\end{array}$ & $\begin{array}{l}\text { defined as factors of people } \\
\text { and the surrounding social } \\
\text { environment that can affect } \\
\text { the use of the system. }\end{array}$ \\
\hline X5 & Task & $\begin{array}{l}\text { The level of compatibility of } \\
\text { system features available } \\
\text { with user requirements. }\end{array}$ \\
\hline X6 & Trust & $\begin{array}{l}\text { The level of user trust in the } \\
\text { system and system provider. }\end{array}$ \\
\hline
\end{tabular}

From Table III. it can be seen that there variable which is a variable whose is influenceing by other variables or also called the independent variable, namely:

\section{RESULT AND DISCUSSION}

\subsection{Data Analysis And Results}

Using SmartPLS software, the next step is to do two stages in data analysis, namely the measurement model or often called the outer model and structural model or often called the inner model. The first stage (Outer model) is conducted to test the characteristics of the data obtained, such as testing the data whether it has followed a normal distribution or not. If it turns out that the data obtained has not met the normal distribution, then the second stage of the analysis process cannot be done. After the first stage is fulfilled, then the next step is to analyze the data according to the hypothesis proposed in this study (Inner model).

\subsection{Measurement Model}

The evaluation of the measurement model (Outer model) is done by testing the convergent validity, testing the discriminant validity and also the reliability test [21].

Convergent validity is tested at the indicator level and its variables. Convergent validity at the indicator level is called indicator reliability. Convergent validity tests are carried out by evaluating the value of loading factors and only accepting indicators with factor loading greater than 0.7 [22]. Whereas Ghozali says it again that the loading value has a high validity level if it has a loading factor value greater than 0.7.

The discriminant validity test is carried out at the indicator level and variable. At the indicator level, Barclay et al in 1995 state that no indicator gives loading to other latent variables higher than the latent variable that should be. Another name that is often used is cross loading [23].

While at the variable level, discriminant validity is assessed using AVE (Average Variance Extracted). Variables must have a value of AVE> 0.5 to be declared valid [22].

The output from SmartPLS shows that all 24 indicators are valid and reliable. Hence, we can continue to the next stage which is the structural model. The measurement model results are presented in the following figure.

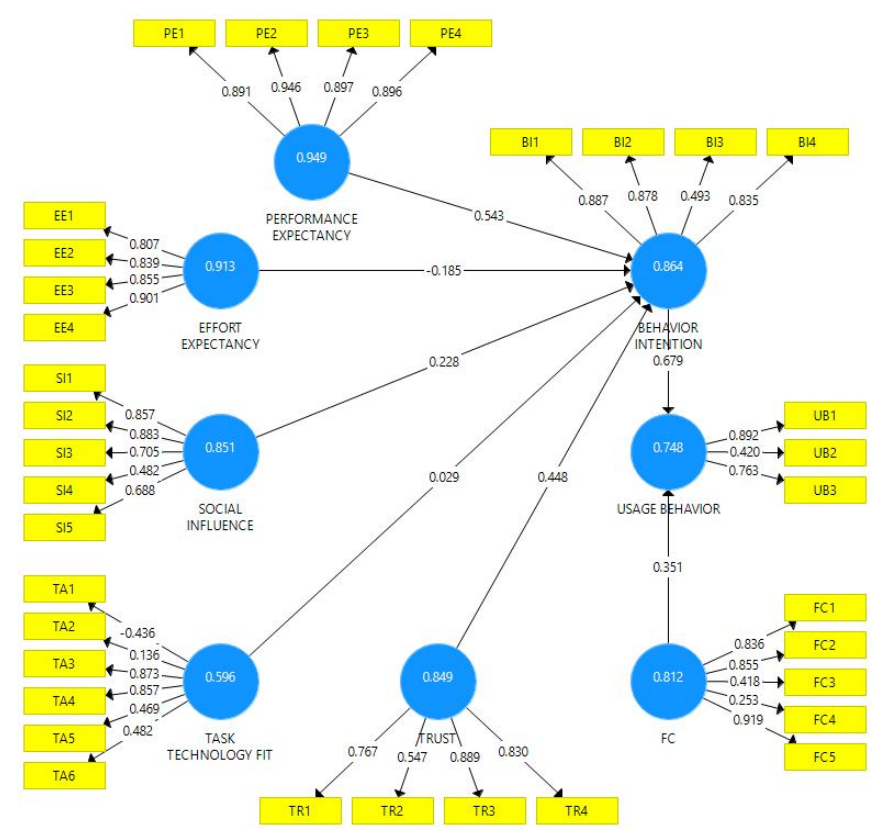

Figure 6: Measurement Model

The following loading factor table shows that all indicators have met the criteria of convergent validity. In addition to the result of the loading factor, here is the result of cross loading.

Table 4: Loading Factor.

\begin{tabular}{ccc}
\hline Variable & Code & $\begin{array}{c}\text { Loading } \\
\text { Factor }\end{array}$ \\
\hline \multirow{3}{*}{ Performance Expectancy } & PE1 & 0.870 \\
\cline { 2 - 3 } & PE2 & 0.911 \\
\cline { 2 - 3 } & PE3 & 0.864 \\
\cline { 2 - 3 } Effort Expectancy & PE4 & 0.866 \\
\cline { 2 - 3 } & EE1 & 0.790 \\
\cline { 2 - 3 } Social Influence & EE2 & 0.864 \\
\cline { 2 - 3 } & EE3 & 0.863 \\
\cline { 2 - 3 } & EE4 & 0.811 \\
\cline { 2 - 3 } Facilitating Conditions & SI2 & 0.904 \\
\cline { 2 - 3 } & SI3 & 0.950 \\
\cline { 2 - 3 } & FC1 & 0.730 \\
\cline { 2 - 3 } Task Technology-Fit & FC2 & 0.851 \\
\cline { 2 - 3 } & FC5 & 0.882 \\
\cline { 2 - 3 } Trust & TA3 & 0.853 \\
\hline & TA4 & 0.831 \\
\hline & TR1 & 0.999 \\
\hline
\end{tabular}


Nilo Legowo et al., International Journal of Advanced Trends in Computer Science and Engineering, 9(1), January - February 2020, 42 - 50

\begin{tabular}{ccc}
\hline & TR4 & 0.880 \\
\hline \multirow{3}{*}{ Behavior Intention } & BI1 & 0.868 \\
\cline { 2 - 3 } & BI2 & 0.901 \\
\cline { 2 - 3 } & BI4 & 0.930 \\
\hline Usage Behavior & $\mathrm{UB} 1$ & 0.883 \\
\cline { 2 - 3 } & $\mathrm{UB} 3$ & 0.879 \\
\hline
\end{tabular}

At the variable level, discriminant validity is assessed using AVE (Average Variance Extracted). Variables must have a value of $A V E>0.5$ to be declared valid [21]. The following AVE table shows that al variables have passed the discriminant validity's criteria, which is AVE $>0.5$.

Table 5: Average Variance Extracted (AVE).

\begin{tabular}{lc}
\hline \multicolumn{1}{c}{ Variable } & Value of AVE \\
\hline Performance Expectancy & 0.771 \\
\hline Effort Expectancy & 0.693 \\
\hline Social Influence & 0.750 \\
\hline Facilitating Conditions & 0.743 \\
\hline Task Technology-Fit & 0.844 \\
\hline Trust & 0.679 \\
\hline Behavior Intention & 0.810 \\
\hline Usage Behavior & 0.776 \\
\hline
\end{tabular}

While at the indicator level, discriminant validity is tested at the indicator level using cross leading result from SmartPLS. Please refer to cross loading table below for the results.

The shaded section in table 6 shows that the variable correlation value with the corresponding indicator has a higher value than the correlation value with other variables. Therefore, based on the cross-loading table, all indicators have the highest value on their variables compared to the values on other variables so that all indicators are declared valid.

Last but not least of the measurement model is the reliability test using composite reliability and Cronbach alpha. The table below shows that all variables are reliable.

Table 6: Reliability Test.

\begin{tabular}{lcc}
\hline \multicolumn{1}{c}{ Variable } & $\begin{array}{c}\text { Cronbach's } \\
\text { Alpha }\end{array}$ & $\begin{array}{c}\text { Composite } \\
\text { Reliability }\end{array}$ \\
\hline Performance Expectancy & 0.901 & 0.931 \\
\hline Effort Expectancy & 0.855 & 0.900 \\
\hline Social Influence & 0.833 & 0.899 \\
\hline Facilitating Condition & 0.827 & 0.897 \\
\hline Task Technology-Fit & 0.890 & 0.915 \\
\hline Trust & 0.770 & 0.864 \\
\hline
\end{tabular}

\begin{tabular}{lll}
\hline Behavior Intention & 0.883 & 0.927 \\
\hline Usage Behavior & 0.711 & 0.874 \\
\hline
\end{tabular}

\subsection{Structural Model}

Evaluation of the structural model (inner model) is done to see the significance level of the relationship between the dependent variable and the independent variable. Evaluation of structural models can be done after evaluation of the measurement model shows good results, namely the fulfillment of the validity test and reliability test.

The structural model is evaluated using R-Square (R2) and also an analysis of the significant value of the path coefficient. The variable is declared to have a significant effect if the T-statistic value is more than 1.96 and the P-Value is lest than 0.05. The fig. 7 shows the path diagram of the structural model that is run on Smart PLS.

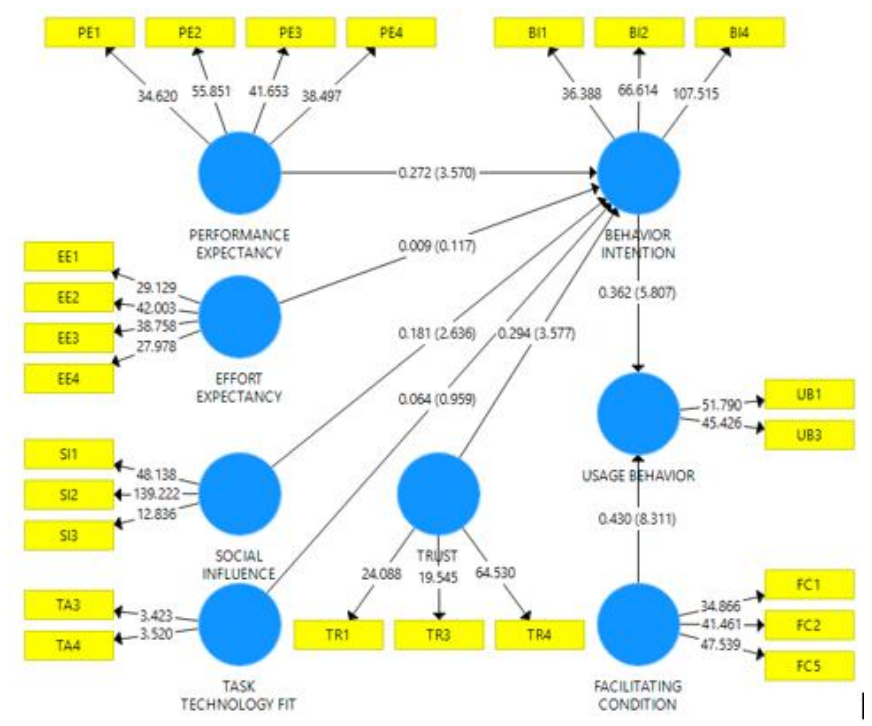

Figure 7: Structural Model

Based on the path coefficients table, performance expectancy (PE), social influence (SI) and trust (TR) have a significant effect on the behavior intention (BI) because the T-statistic value is more than 1.96 and the P-Value is lest than 0,05 . While the technology-fit task (TA) does not affect the behavior intention (BI) because it does not meet the requirements of the Statistical T-value greater than 1.96 and the P-value of values is greater than 0.05. And the intention behavior (BI) and facilitating conditions (FC) affect the use behavior (UB).

The value of R-square (R2) of the dependent variables, in this case, the intention behavior (BI) and use behavior (UB) is used assess the power to explain (explanatory power) from the model used in the study.

For use behavior, the value of R-Square $0.461 \%$ indicates that use behavior is influenced by the behavior intention and facilitating conditions of $0.461 \%$ and also influenced by 
$0.539 \%$ by other variables that need to be further investigated. The following tables show the path coefficient and R-Square results.

Table 7: Path coefficient.

\begin{tabular}{lccccc}
\hline & $\begin{array}{c}\text { Original } \\
\text { Sample } \\
(\mathbf{O})\end{array}$ & $\begin{array}{c}\text { Sample } \\
\text { Mean } \\
(\mathbf{M})\end{array}$ & $\begin{array}{c}\text { Standard } \\
\text { Deviation } \\
(\text { STDEV })\end{array}$ & $\begin{array}{c}\text { T Statistics } \\
(\mid \text { O/STDEV })\end{array}$ & P-Values \\
\hline $\mathrm{PE} \rightarrow \mathrm{BI}$ & 0.272 & 0.272 & 0.076 & 3.570 & 0.000 \\
\hline $\mathrm{EE} \rightarrow \mathrm{BI}$ & 0.009 & 0.015 & 0.080 & 0.117 & 0.907 \\
\hline $\mathrm{SI} \rightarrow \mathrm{BI}$ & 0.181 & 0.177 & 0.069 & 2.636 & 0.009 \\
\hline $\mathrm{FC} \rightarrow \mathrm{UB}$ & 0.430 & 0.431 & 0.052 & 8.311 & 0.000 \\
\hline $\mathrm{TA} \rightarrow \mathrm{BI}$ & 0.064 & 0.045 & 0.067 & 0.959 & 0.338 \\
\hline $\mathrm{TR} \rightarrow \mathrm{BI}$ & 0.294 & 0.296 & 0.082 & 3.577 & 0.000 \\
\hline $\mathrm{BI} \rightarrow \mathrm{UB}$ & 0.362 & 0.367 & 0.062 & 5.807 & 0.000 \\
\hline
\end{tabular}

\section{CONCLUSION}

Based on the results of research on the evaluation of internet banking system using the UTAUT method combined with the Task Technology-Fit model and the Trust model which has been gone through analysis and hypothesis testing, conclusions can be taken as follows:

The results of the study that performance expectancy has a significant effect on Behavior Intention on the Internet Banking (IB) system. Performance expectancy measures the user's perceptions of the usefulness and benefits of the IB system. With the acceptance of this hypothesis, it can be interpreted that the speed and flexibility to access the banking system influence the behavior intention to use the IB system.

Effort expectancy does not affect the user's intention to use the IB system. Because most users already have experienced using the IB system from other competitors so users do not see any need to specifically learn how to use the IB system. So that effort expectancy does not give effect to the behavior intention in the context of the IB system at bank. Social influence has a effect to the behavior intention on the use of the IB system.

Facilitating Condition has a significant effect on Use Behavior on the use of the IB system, FC have the highest influence on use behavior compared to other variables. This proves that based on the data obtained in the field, respondents see compatibility factors as the most influencing level of adoption of the IB system.

Task technology-fit is related to the compatibility between the features available on the IB system and the user's needs. The results of the research show that technology-fit tasks do not affect Behavior intention to use the IB system. Based on the obtained information, when the IB system was first launched, the customers of bank immediately intended to use the IB system without first considering whether the IB system has features that suit their needs or not.

Trust has a significant effect on the behavior intention on the use of the IB system. This proves that the intention to use the IB system is largely determined by how the user sees the bank as a competent and trusted party. Therefore banks need to maintain user trust by ensuring the security and convenience of using the IB system.

Finally, behavior intention has a significant effect on use behavior on the use of the IB system. Behavior intention provides the second-largest influence after facilitating conditions on the level of adoption of the use of the IB system.

\section{REFERENCES}

1. Yani, Evi \& Fitria Lestari, Ade \& Amalia, Hilda \& Puspita, Ari. "Pengaruh Internet Banking Terhadap Minat Nasabah Dalam Bertransaksi Dengan Technology Acceptance Model" Jurnal Informatika, 5, pp.34-42, 2018. https://doi.org/10.31311/ji.v5i1.2717

2. Lee, Ming-Chi "Factors influencing the adoption of internet banking: An integration of TAM and TPB with perceived risk and perceived benefit". Electronic Commerce Research and Applications. 2009 https://doi.org/10.1016/j.elerap.2008.11.006

3. Barusman, Y. S. "Pemanfaatan E-banking Dalam Industri Perbankan Ditinjau Dari Structure-Conduct-Performance Paradigm di Indonesia”, Jurnal Manajemen dan Bisnis, 1, Pp. 1-20, 2010.

4. V. Goyal, U.S.Pandey, and S. Batra, "Mobile Banking in India: Practices, Challenges and Security Issues," International Journal of Advanced Trends in Computer Science and Engineering, vol. 1, no. June, pp. 56-66, 2012.

5. Venkatesh, V., Morris, M. G., Davis, G. B., Davis, F. D. User acceptance of Information Technology: Toward a Unified View. MIS Quarterly, 27(3), 25-478, 2003. https://doi.org/10.2307/30036540

6. Bushati, B., Šehović, D., \& Binaj, I. The Importance of Information Technology Use in Business Management, 2015. [Electronic version]. Available: http://www.mcser.org/journal/index.php/ajis/article/vie w/7196 [2018, July 20]

7. Warshaw, P., \& Davis, F. "The accuracy of behavioral intention versus behavioral expectation for predicting behavioral goals" The Journal of Psychology, 119(6) ,pp. 599-602, 1985. https://doi.org/10.1080/00223980.1985.9915469

8. Mayer, R.C., Davis, J.H., Schoorman, F.D. "An Integrative Model of Organizational Trust". Academy of Management Review: 20 (3), pp709-734, 1995.

9. Hofstede, Geert. "Culture's Consequenses: International Differences in Work-Related Values". California: SAGE Publications, Inc. 1980.

10. Zand, D. E.. Trust and managerial problem solving. Administrative Science Quarterly, 17, pp 229-239, 1972. https://doi.org/10.2307/2393957 
11. McFall, L. "Integrity Ethics”, 98, pp 5-20, 1987.

12. Goodhue, D., \& Thompson, R. L. "Task-technology fit and individual performance". MIS Quarterly, 19, pp 213-236, 1995,.

13. Oliveira, Tiago \& Faria, Miguel \& Thomas, Manoj \& Popovič, Aleš. "Extending the understanding of mobile banking adoption: When UTAUT meets TTF and ITM". International Journal of Information Management, 34, pp 689-703, 2014.

14. Yoo, S. J., Han, S. H., \& Huang, W. "The roles of intrinsic motivators and extrinsic motivators in promoting e-learning in the workplace: A case from South Korea", Computers in Human Behavior, 28(3), pp 942-950, 2012.

https://doi.org/10.1016/j.chb.2011.12.015

15. Yue Guo \& Stuart J. Barnes "Explaining Purchasing Behavior within World of Warcraft. Journal of Computer Information Systems", 52(3), pp 18-30, 2012.

16. Venkatesh, Viswanath., Thong, James Y. L., and Xu, Xin. "Unified Theory of Acceptance and Use of Technology: A Synthesis and the Road Ahead". Journal of the Association for Information Systems, , 17(5), 2016.

17. Zhou, Tao \& Lu, Yaobin \& Wang, Bin. "Integrating TTF and UTAUT to explain mobile banking user adoption". Computers in Human Behavior, 26, pp 760-767, 2010.

18. Venkatesh, V., and David, M.P. "Cheiloscopy: an aid for personal identification”. Journal of Forensic Dental Sciences, 3, pp 67-70, 2011. https://doi.org/10.4103/0975-1475.92147

19. Miltgen, C. L., Popovic, A., \& Oliveira, T. "Determinants of end-user acceptance of biometrics: Integrating the "Big 3" of technology acceptance with privacy context. 56, pp 103-114, 2013.

20. Lian, J., \& Yen, D.C. “Online shopping drivers and barriers for older adults: Age and gender differences" Computers in Human Behavior, 37, pp 133-143, 2014.

https://doi.org/10.1016/j.chb.2014.04.028

21. Ghozali, Imam. "Aplikasi Analisis Multivariate dengan Program SPSS" Semarang: Badan Penerbit Universitas Diponegoro. 2008.

22. Pan, T. "Factors Affecting Mobile Gaming Adoption -A Study of Chinese Users and Contexts", 2011.

23. Barclay, D. W., Higgins, C. A., \& Thompson, R. "The partial leastsquares approach to causal modeling: personal computer adoption and use as illustration.Technology Studies, 2(2), pp 285-309,1995. 